\title{
Breast T-Cell Non-Hodgkin Lymphoma
}

National Cancer Institute

\section{Source}

National Cancer Institute. Breast T-Cell Non-Hodgkin Lymphoma. NCI Thesaurus. Code C5182.

A T-cell non-Hodg kin lymphoma that arises from the breast as a primary tumor. Primary T-cell non-Hodgkin lymphomas of the breast are rare. 